\title{
Carbon dioxide system in the Canary region during October 1995*
}

\author{
J.M. SANTANA-CASIANO, M. GONZÁLEZ-DÁVILA, L.M. LAGLERA-BAQUER \\ and M.J. RODRIGUEZ-SOMOZA
}

Departamento de Química, Universidad de Las Palmas de Gran Canaria, 35017 Las Palmas de Gran Canaria, Spain. E-mail:magda@cicei.ulpgc.es

\begin{abstract}
SUMMARY: During the cruise F/S Poseidon 212/3 (September 30-October 8, 1995) determination of carbon system variables was carried out over the section of La Palma-La Graciosa and at the ESTOC station in the Canary Island area. Total alkalinity and $\mathrm{pH}$ in the total scale at $25^{\circ} \mathrm{C}$ were determined at 24 stations from surface to bottom. In this area, the presence of different water masses can be traced by the carbon system variables. NACW is defined by a strong gradient of $\mathrm{A}_{\mathrm{T}}$ and $\mathrm{pH}$ from 150 to $750 \mathrm{~m}$. MW is characterised by high values of $\mathrm{A}_{\mathrm{T}}$ and $\mathrm{pH}$ between 1000 to $1200 \mathrm{~m}$ and AAIW signals are found at around $900 \mathrm{~m}$ in the strait between Gran Canaria and Fuerteventura with low $\mathrm{A}_{\mathrm{T}}$, low pH and a maximum of $f \mathrm{CO}_{2}$ Assuming an atmospheric mean value of $f \mathrm{CO}_{2}$ of $360 \mu \mathrm{atm}$ and an average surface value of $393 \pm 7 \mu \mathrm{atm}$, we can conclude that during this cruise this oceanic area tends to release $\mathrm{CO}_{2}$ into the atmosphere, acting as a weak source with a carbon flux towards the atmosphere of $+8.0 \pm 1.8 \mathrm{mmol} \cdot \mathrm{m}^{-2} \mathrm{~d}^{-1}$. The saturation levels in the Canary Island area have been found to be higher than $3600 \mathrm{~m}$ for calcite and $2700 \mathrm{~m}$ for aragonite. The inorganic carbon/organic carbon ratio (IC/OC) varies from 0.07 at $300 \mathrm{~m}$ to 0.5 at $3000 \mathrm{~m}$. The IC/OC ratio shows that about a $34 \%$ increase in the $\mathrm{C}_{\mathrm{T}}$ of the deep water is contributed by the inorganic $\mathrm{CaCO}_{3}$ dissolution. The IC at $300 \mathrm{~m}$ is around $7 \mu \mathrm{mol} \mathrm{kg}$, increasing with depth to $37.5 \mu \mathrm{mol} \mathrm{kg}^{-1}$ at $3700 \mathrm{~m}$.
\end{abstract}

Key words: carbonate system, $\mathrm{pH}_{\mathrm{T}}$, total alkalinity, total inorganic carbon, $\mathrm{CO}_{2}$ fugacity.

\section{INTRODUCTION}

The carbonate system in seawater is one of the most complex topics in oceanography. The system has long interested many oceanographers from various fields since it plays an important role in the biogeochemical cycles of three sub-spheres of the Earth, the biosphere, the lithosphere, and the hydrosphere (Chen and Wang 1995). More recently, the fate of fossil fuel $\mathrm{CO}_{2}$ has promoted interest in the study of carbonate chemistry in the oceans, because of the

\footnotetext{
*Received October 1, 1999. Accepted May 15, 2000.
}

greenhouse effect of carbon dioxide on the global climate. Oceanic uptake is a key part of the global budget of the $\mathrm{CO}_{2}$ released into the atmosphere by human activities. Present estimates indicate that about $40 \%$ of the anthropogenic $\mathrm{CO}_{2}$ added to the atmosphere due to the burning of fossil fuels is absorbed by the oceans (Post et al., 1990; Hougton et al., 1995). The capacity of the oceans for uptake of $\mathrm{CO}_{2}$ depends on the inorganic carbon chemistry and also depends greatly on many factors such as hydrography, circulation of water masses, mixedlayer dynamics, wind stresses and the biological processes in the ocean (Broecker and Peng, 1982). 


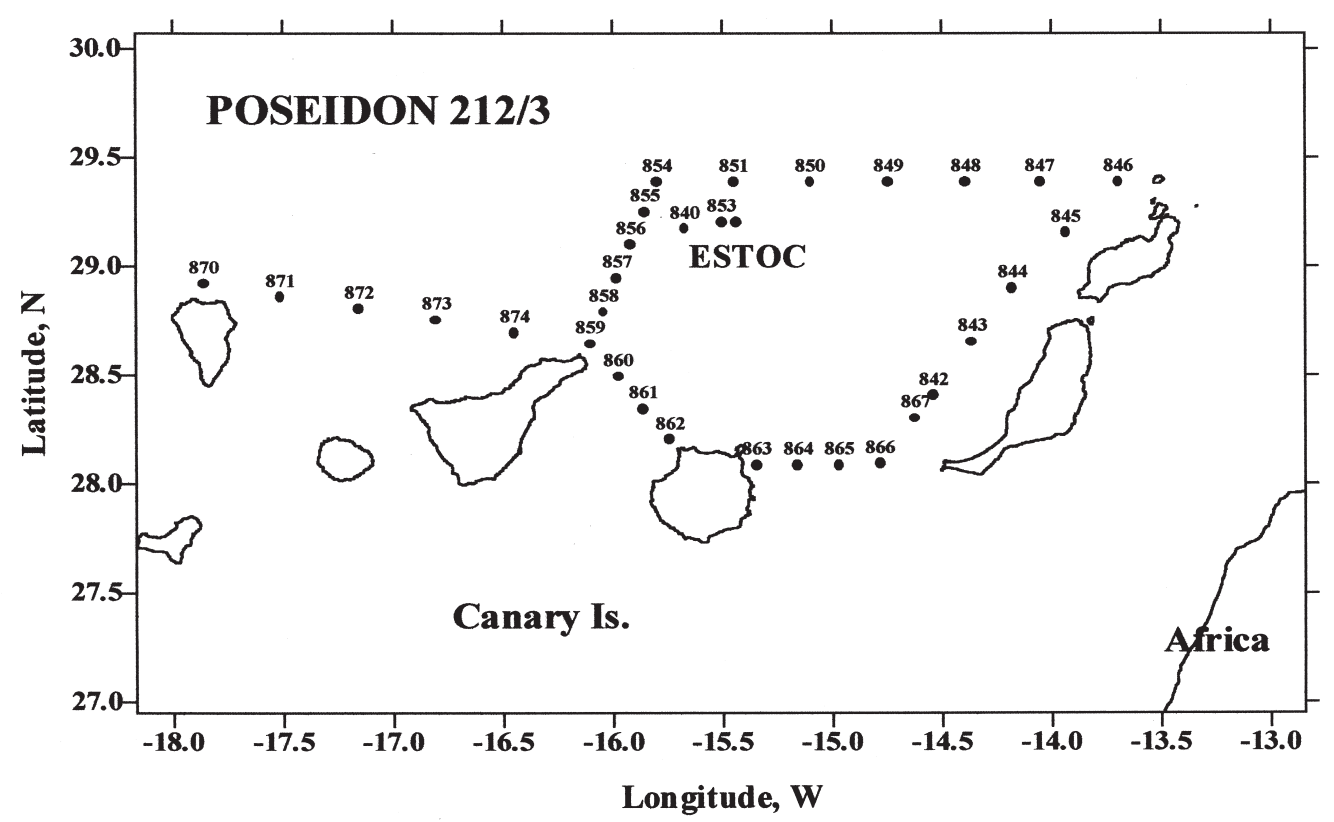

FIG. 1. - The Northeast Atlantic Ocean at the Canary Islands and stations grid for POSEIDON 212/3 cruise (September 30 - October 8 , 1995).

The North Atlantic, with oceanic high latitude regions of deep water formation, mid-latitude sites of mode water formation and subtropical oligotrophic oceans, is thought to be a large sink for atmospheric $\mathrm{CO}_{2}$ (Tans et al., 1990; Takahashi et al., 1993, 1995). The Canary Oceanic region (Fig. 1) is situated in a peculiar area $100-600 \mathrm{~km}$ west of the NW African coast in the eastern extensions of the subtropical North Atlantic gyre at a latitude of 27$28^{\circ} \mathrm{N}$. It is part of the recirculation regime linking the Gulf Stream with the North Equatorial Current via the Azores and Canary Currents (Stramma and Siedler, 1988, Klein and Siedler, 1989). The structure of the Canary Current System is strongly influenced by the seasonally varying trade winds and the resulting upwelling regime off North-West Africa (Stramma and Siedler, 1988). The thermohaline properties of water masses involved in the water column in the Eastern North Atlantic have been extensively described in previous studies (Broecker and Takahashi, 1981, Arhan et al.,1994, Measures et al, 1995). Below North-Atlantic Central Water (NACW), the penetration and influence of both Antarctic Intermediate Water (AAIW) at around 900 $\mathrm{m}$ and Mediterranean Water (MW) between 900 and $1500 \mathrm{~m}$ are clearly observed in the North Atlantic (Fig. 2a).

During the Poseidon 212/3 cruise (30 September8 October 1995), the determination of carbon system variables was carried out north of the Canary Islands between La Palma and La Graciosa. Total alkalinity and $\mathrm{pH}$ at total scale and at $25^{\circ} \mathrm{C}$ were determined at 24 stations from surface to bottom. The main objective of this work was to study for the first time the carbon cycle in this area in order to evaluate the capacity of the zone for removing anthropogenic carbon dioxide from the atmosphere and to calculate both the saturated state of $\mathrm{CaCO}_{3}$ and the ratio of in situ inorganic and organic carbon decomposition (IC/OC).

\section{EXPERIMENTAL}

pH

The $\mathrm{pH}$ in total scale $\left(\mathrm{mol} \mathrm{kg}{ }^{-1}\right)$ was measured at $25^{\circ} \mathrm{C}$ using the potentiometric technique. The electrodes used to measure the e.m.f. of the sample consisted of a ROSS glass $\mathrm{pH}$ electrode and an Orion double junction $\mathrm{Ag} / \mathrm{AgCl}$ reference electrode, connected to an Orion 720A pH meter. The electrodes were calibrated using a TRIS/HCl buffer in synthetic seawater with a salinity of 35 and corrected following the last recommendations by DelValls and Dickson (1998) and Lee et al. (2000). The tris buffer and the seawater samples were measured at $25^{\circ} \mathrm{C}$, which allows the e.m.f. of the $\mathrm{pH}$ cell to be measured, first in the tris buffer and then in the seawater sample. The $\mathrm{pH}$ of the unknown seawater samples was determined according to standard operating procedures (Dickson and Goyet, 1994). 
Repeatedly, seawater measurements of different CRM (certified reference material) samples $(n=54)$ gave a standard deviation of $\pm 0.003 \mathrm{pH}$ units.

\section{Total alkalinity}

The total alkalinity of seawater $\left(\mathrm{A}_{\mathrm{T}}\right)$ was determined by titration with $\mathrm{HCl}$ to the carbonic acid end point using two potentiometric systems and described in more detail in Mintrop et al. (2000). The $\mathrm{HCl}$ solution $(251,0.25 \mathrm{M})$ was made from concentrated analytical grade $\mathrm{HCl}\left(\right.$ Merck $^{\circledR}$, Darmstadt, Germany) in $0.45 \mathrm{M} \mathrm{NaCl}$, in order to yield an ionic strength similar to open ocean seawater. The acid was standardised by titrating weighed amounts of $\mathrm{Na}_{2} \mathrm{CO}_{3}$ dissolved in $0.7 \mathrm{M} \mathrm{NaCl}$ solutions. The total alkalinity of seawater was evaluated from the proton balance at the alkalinity equivalence point, $\mathrm{pH}_{\text {equiv }}=$ 4.5 , according to the exact definition of total alkalinity (Dickson, 1981). The performance of the titration systems was monitored by titrating different samples of certified reference material (CRM, batch \#35) that have known inorganic carbon and $A_{T}$ values. The agreement between our data and certified

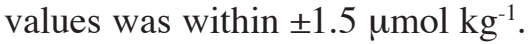

\section{Total inorganic carbon and $\mathrm{fCO}_{2}$}

Total inorganic carbon $\left(\mathrm{C}_{\mathrm{T}}\right)$ and $f \mathrm{CO}_{2}$ were computed from experimental values of $\mathrm{pH}_{\mathrm{t}}$ and total alkalinity using the carbonic acid dissociation constants of Dickson and Millero (1987) following the last suggestions by Lee et al. (2000). Considering the accuracy of potentiometric $\mathrm{pH}( \pm 0.005)$ and potentiometric total alkalinity $\left( \pm 1 \mu \mathrm{mol} \mathrm{kg}{ }^{-1}\right)$ determinations (Mintrop et al., 2000), the accuracy of $\mathrm{C}_{\mathrm{T}}$ and $f \mathrm{CO}_{2}$ values are $\pm 4 \mu \mathrm{mol} \mathrm{kg}{ }^{-1}$ and $\pm 5 \mu \mathrm{atm}$, respectively (Millero, 1995; Lee et al., 1997).

\section{RESULTS AND DISCUSSION}

\section{pH and alkalinity vertical profiles}

Seawater $\mathrm{pH}$ reflects the status of the carbon dioxide system, which provides the major shortterm $\mathrm{pH}$ buffer. In turn, the carbonate system is intimately linked with biological productivity through the processes of photosynthesis and respiration. Biotic production and decomposition affect the $\mathrm{pH}$ in line with the equation (Anderson, 1985; Fraga and Perez, 1990; Fraga et al., 1998)

$$
\begin{gathered}
106 \mathrm{CO}_{2}+16 \mathrm{NO}_{3}^{-}+\mathrm{H}_{3} \mathrm{PO}_{4}^{2-}+78 \mathrm{H}_{2} \mathrm{O} \Leftrightarrow \\
\Leftrightarrow \mathrm{C}_{106} \mathrm{H}_{175} \mathrm{O}_{42} \mathrm{~N}_{16} \mathrm{P}+150 \mathrm{O}_{2}
\end{gathered}
$$

The vertical profiles of $\mathrm{pH}$ on a total scale at $25^{\circ} \mathrm{C}$ are shown in Figure $2 \mathrm{~b}$. The $\mathrm{pH}$ reaches a maximum in surface waters $(8.035 \pm 0.005)$ due to photosynthesis. The $\mathrm{pH}$ then decreases due to the oxidation of plant material and exhibits a sharp decrease with depth to approximately $1000 \mathrm{~m}$ coincident with a minimum in $\mathrm{O}_{2}$ and maximum in apparent oxygen utilisation (AOU) (Llinás et al., $1999)$ and $f \mathrm{CO}_{2}$. The lowest values of $\mathrm{pH}$ at around $800-900$ m (open circles in Fig. 2) trace the northward advection of AAIW (Willenbrink, 1982) as a poleward undercurrent of the Canary Current. On the other hand, the highest $\mathrm{pH}_{\mathrm{t}}$ values observed between $800-1000 \mathrm{~m}$ (from 7.75 to 7.82 ) are due to the presence of a Meddy (open triangles) around station 871. Below $1000 \mathrm{~m}$, an increase in $\mathrm{pH}$ is observed due to the dissolution of calcium carbonate and the advection of water masses more ventilated than the intermediate water masses.

The vertical profiles of total alkalinity show a minimum at around $700 \mathrm{~m}\left(2335 \mu \mathrm{mol} \mathrm{kg}{ }^{-1}\right)$, a local alkalinity maximum at $1000 \mathrm{~m}$ associated with the Meddy at station $871\left(2393 \mu \mathrm{mol} \mathrm{kg}^{-1}\right)$, and increasing alkalinity with depth below $1300 \mathrm{~m}$, (Fig. 2c), following the same pattern as the salinity distribution. When the alkalinity is normalized to a constant salinity of $35\left(\mathrm{NA}_{\mathrm{T}}=\mathrm{A}_{\mathrm{T}} / \mathrm{S} \cdot 35\right)$ in order to remove the saline effect over $\mathrm{A}_{\mathrm{T}}$ (Fig. 2e), a typical nutrient profile is obtained, with a surface depletion due to formation of calcium carbonate and regeneration at depth due to the temperature and pressure effect on the solution equilibrium of calcium carbonate.

Figures $2 \mathrm{~d}$ and $2 \mathrm{f}$ show the distribution of computed $\mathrm{C}_{\mathrm{T}}$ and $\mathrm{NC}_{\mathrm{T}}\left(\mathrm{NC}_{\mathrm{T}}=\mathrm{C}_{\mathrm{T}} / \mathrm{S} \cdot 35\right)$ in the water column for the most representative stations sampled during the Poseidon 212/3 cruise. The maximum values of $\mathrm{C}_{\mathrm{T}}$ were found in the deepest and less saline waters, NADW, and in the saline core of Mediterranean water (open triangles). The redissolution of calcium carbonate and remineralisation of organic matter is responsible for the increase of $\mathrm{C}_{\mathrm{T}}$ in NADW, whereas the high values of $\mathrm{C}_{\mathrm{T}}$ in $\mathrm{MW}$ are due to the saline contribution. The $\mathrm{C}_{\mathrm{T}}$ concentration decreases towards the surface layer due to the uptake of the same by the phytoplankton. Thus, the MW shows a clear signal by its low $\mathrm{NC}_{\mathrm{T}}(2117 \mu \mathrm{mol}$ $\left.\mathrm{kg}^{-1}\right)$, high $\mathrm{A}_{\mathrm{T}}\left(2393 \mu \mathrm{mol} \mathrm{kg}^{-1}\right)$ and relatively high $\mathrm{pH}$. In the strait between Gran Canaria and Fuerteventura (stations 863-865, open circles in Fig. 

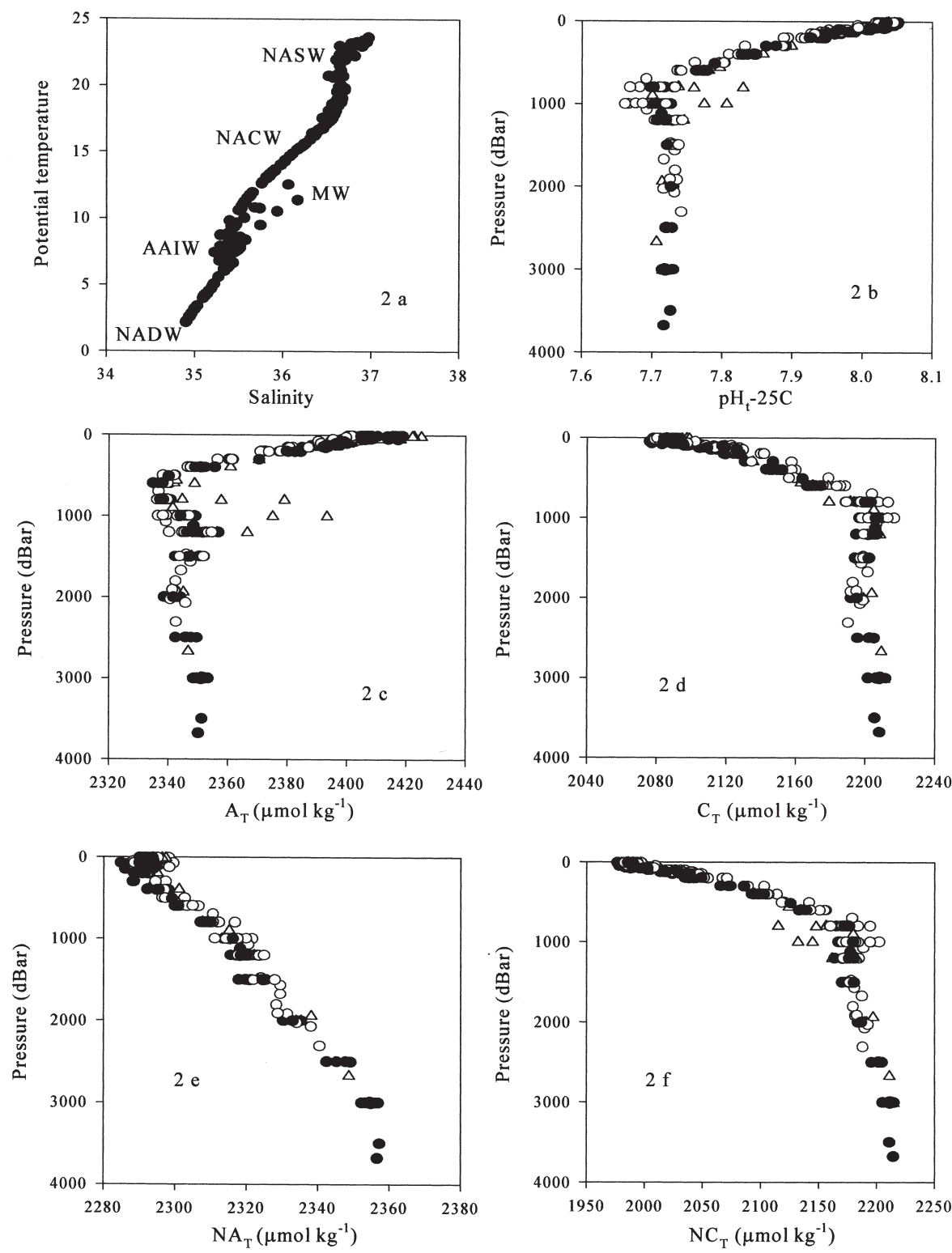

FIG. 2. - Potential temperature-salinity plot (a), $\mathrm{pH}_{-}-25^{\circ} \mathrm{C}$ profile (b), total alkalinity ( $\mu \mathrm{mol} \mathrm{kg}{ }^{-1}$ ) profiles (c), computed total inorganic carbon $\mathrm{C}_{\mathrm{T}}\left(\mu \mathrm{mol} \mathrm{kg}^{-1}\right)$ profiles $(\mathrm{d})$, normalised $(\mathrm{S}=35)$ total alkalinity $\left(\mathrm{NA}_{\mathrm{T}}\right)(\mathrm{e})$ and normalised $(\mathrm{S}=35)$ total inorganic carbon $\mathrm{NC}_{\mathrm{T}}$ profiles $(\mathrm{f})$ over selected stations. Open circles correspond to stations 863-867 and 842-846 in the eastern part, closed circles correspond to ESTOC station (stations 840,853 and 869 ) and open triangles to stations 870 and 874 in the western part.

2) the influence of AAIW is shown by its low $\mathrm{pH}$

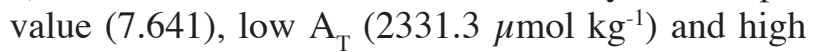
$\mathrm{C}_{\mathrm{T}}\left(2205.3 \mu \mathrm{mol} \mathrm{kg}^{-1}\right)$ (high $\mathrm{C}_{\mathrm{T}}$ to $\mathrm{A}_{\mathrm{T}}$ ratio). Below the MW core and the poleward intrusion of AAIW, there is a relatively homogenous layer in $\mathrm{pH}$ in comparison with the immediately higher layer.

\section{Alkalinity and $f \mathrm{CO}_{2}$ sections}

The water mass characteristics observed during the Poseidon 212/3 cruise can be considered typical for the beginning of autumn: high temperature at the surface and a well-developed thermocline. Figure 3 shows the alkalinity variability over the La Palma-La Graciosa section. The presence of North-Atlantic Central Water (NACW) from 150 to $750 \mathrm{~m}$ shows a strong gradient of alkalinity. In the intermediate water from 750 to $1500 \mathrm{~m}$ the influence of both Mediterranean Water (MW) and Antarctic Intermediate Water (AAIW) is clearly observed. The influence of AAIW has been found by Rios et al. (1992) at $24^{\circ} \mathrm{N}$ and $22^{\circ} \mathrm{W}$ with minimum salinity $(\mathrm{S}<35.4)$. The minimum salinity in the AAIW corresponds a layer of minimum $\mathrm{pH}$ 


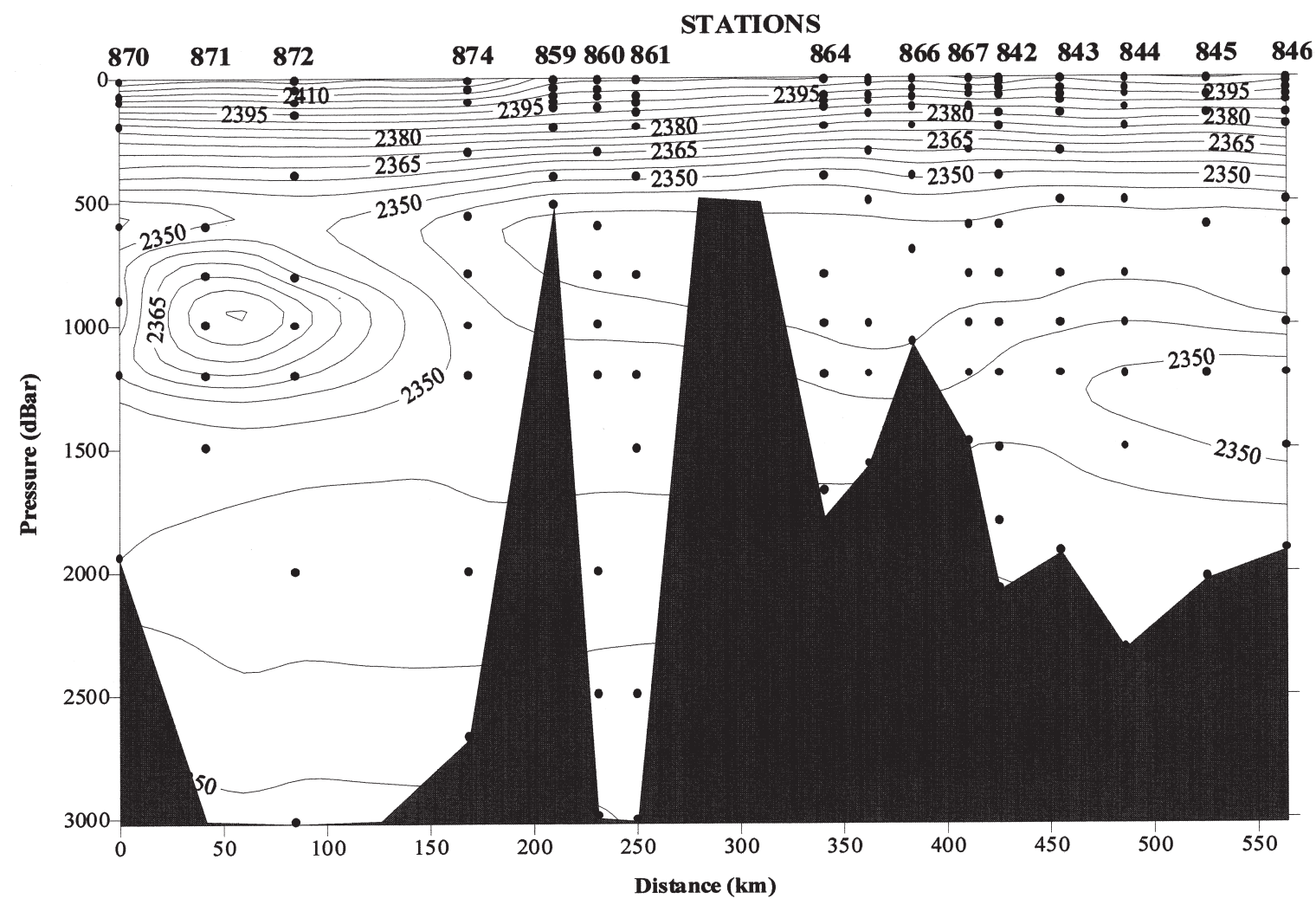

FIG. 3. - Distribution of total alkalinity $\mathrm{A}_{\mathrm{T}}\left(\mu \mathrm{mol} \mathrm{kg} \mathrm{kg}^{-1}\right.$ ) for La Palma (Station 870) - La Graciosa (Station 846), to the north of the Canary Islands in October 1995. Hereafter the bottom represents the depth observed at each station and is not a typical bathymetric profile.

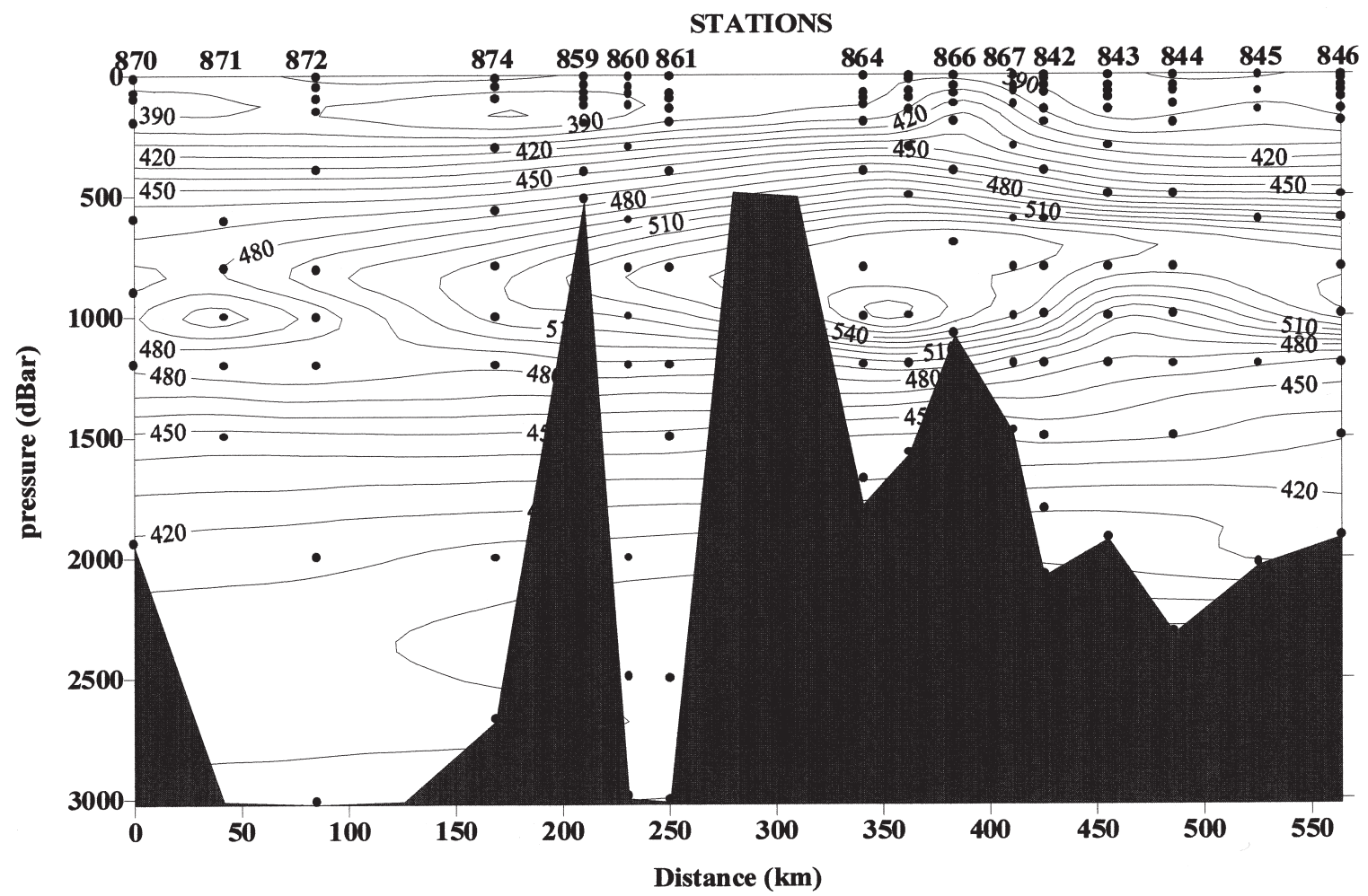

FIG. 4. - The distribution of computed carbon dioxide fugacity ( $\mu \mathrm{atm}$ ) from La Palma (Station 870) - La Graciosa (Station 846), to the north of the Canary Islands in October 1995. 
(Fig. 2b), minimum alkalinity (Fig. 3) and maximum $f \mathrm{CO}_{2}(592 \mu \mathrm{atm})$ (Fig. 4) between stations 864 and 866, which correspond with the inflow of AAIW through the strait between Gran Canaria and Fuerteventura. This maximum fugacity is also observed at station 846 (La Graciosa). This northern salinity minimum is the result of the northward and eastward advection of AAIW within the Gulf Stream-North Atlantic Current system (Measures et al., 1995). The influence of AAIW in this area has also been traced by minimum values of oxygen and slightly higher nutrient concentrations (mainly silicate) by Llinás et al. (1999). The maximum salinity at around $1200 \mathrm{~m}$ with high values of alkalinity and total dissolved inorganic carbon is due to Mediterranean water (Fig. 2d). At station 871, a high maximum salinity denotes the presence of a Meddy. This Meddy also shows a relative maximum of pH (Fig. 2b) and a sharp increase in alkalinity (Figs. 2c and 3).

The surface values of computed $\mathrm{fCO}_{2}$ for this time of the year clearly show that this area is acting as a source of $\mathrm{CO}_{2}$. Assuming a mean atmospheric value of $f \mathrm{CO}_{2}$ of $360 \mu \mathrm{atm}$ and surface values of 385 to $400 \mu \mathrm{atm}$, we found that during this cruise this oceanic area tends to release $\mathrm{CO}_{2}$ into the atmosphere. The air-sea $\mathrm{CO}_{2}$ exchange $\left(\mathrm{mmol} \cdot \mathrm{m}^{-2} \cdot \mathrm{d}^{-1}\right)$ is calculated using the following equation

$$
\mathrm{FCO}_{2}=0.24 \cdot \mathrm{k} \cdot \mathrm{S} \cdot\left(f \mathrm{CO}_{2, \mathrm{sw}}-f \mathrm{CO}_{2, \mathrm{air}}\right)
$$

where $\mathrm{k}$ is the liquid phase gas transfer velocity $\left(\mathrm{cm} \cdot \mathrm{h}^{-1}\right)$ and $\mathrm{S}$ is the $\mathrm{CO}_{2}$ seawater solubility $\left(\mathrm{mol} \cdot \mathrm{kg}^{-1} \mathrm{~atm}^{-1}\right)$ (Weiss 1974). The effect of wind speed on the transfer velocity, $\mathrm{k}$, is obtained from the equation (Wanninkhof, 1992)

$$
\mathrm{k}=\left(0.31 * \mathrm{U}_{10}{ }^{2}\right) \cdot(660 / \mathrm{Sc})^{-1 / 2}
$$

$\mathrm{U}_{10}$ is the wind speed at a height of $10 \mathrm{~m}\left(\mathrm{~m} \mathrm{~s}^{-1}\right)$. The averaged wind speed during this cruise was $10 \pm 3$ $\mathrm{m} \mathrm{s}^{-1}$. The Schmidt number, Sc, is determined from a third-order polynomial fit for the temperature dependence (Wanninkhof, 1992).

The resulting air-sea $\mathrm{CO}_{2}$ flux was $+8.0 \pm 1.8$ $\mathrm{mmol} \cdot \mathrm{m}^{-2} \cdot \mathrm{d}^{-1}$. Considering the observed variability of $f \mathrm{CO}_{2}$ in this area in 1996-1997 (González-Dávila et al., 2000), this positive $\mathrm{CO}_{2}$ flux can be considered as a maximum value on an annual scale. However, on the same scale this value is clearly compensated, showing this area as a slight sink of $\mathrm{CO}_{2}$ (Takahashi et al., 1997)

\section{State of saturation}

The precipitation or formation of solid $\mathrm{CaCO}_{3}$ in surface waters and the dissolution of solid $\mathrm{CaCO}_{3}$ in deep water is very important in transferring $\mathrm{CO}_{2}$ from surface waters to deep waters. A close coupling of seasonal phytoplankton maxima and particle flux peaks at the ESTOC station has been found (Neuer et al., 1994). This characteristic of many areas of the Atlantic has been demonstrated in the Sargasso Sea by Deuer et al. (1990) and in the North Atlantic Bloom Experiment (NABE , $47^{\circ} \mathrm{N}, 20^{\circ} \mathrm{W}$ ) by Newton et al. (1994). It was mediated by rapid transfer of surface water production to deep ocean. The saturation state of seawater with respect to a carbonate phase $(\Omega i)$ can be determined by calculating the ratio of the measured total ion concentration product to the apparent solubility product of carbonate $\mathrm{i}\left(\mathrm{K}_{\mathrm{sp}, \mathrm{i}}\right)$ according to Equation 4. The thermodynamic index of the apparent solubility product from which the degree of saturation is calculated depends on $f \mathrm{CO}_{2}$ and $\mathrm{pH}$, pressure, $\mathrm{T}$ and mineralogy (aragonite or calcite).

$$
\Omega_{\mathrm{i}}=\left[\mathrm{Ca}^{2+}\right]\left[\mathrm{CO}_{3}{ }^{2-}\right] / \mathrm{K}_{\mathrm{sp}, \mathrm{i}}{ }^{*}
$$

The surface waters in this area are well supersaturated with respect to both calcite and aragonite. The surface value of $\Omega$ for calcite is $5.6 \pm 0.2$ and 3.6 \pm 0.2 for aragonite, both of which decrease in deep water. Aragonite from pteropodos is more soluble than calcite from foraminifera and coccolithophorids at a given T, p and S. During this cruise total coccolithophore cell densities showed a strong gradient from open ocean localization (station 870)

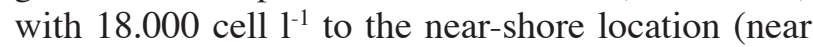
the African coast) with 45.000 cell $\mathrm{1}^{-1}$. Maximum cell densities occurred in the upper photic zone above the deep chlorophyll maximum, which was located between the depth of $50 \mathrm{~m}$ and $125 \mathrm{~m}$ (Knoll et al., 1998).

The saturation level for aragonite is $2700 \mathrm{~m}$ and for calcite is higher than $3500 \mathrm{~m}$. The greater solubility of these minerals in deep waters relates to the effect of pressure on the solubility of $\mathrm{CaCO}_{3(\mathrm{~s})}$.

\section{Inorganic and organic derived carbon}

The processes related to the deep dissolution of $\mathrm{CaCO}_{3}$ and decomposition of organic carbon provide a direct mechanism for the renewal of carbon and related elements in the sea and are of funda- 
mental interest in the biogeochemical cycles of these elements. Studying the nature of the particulate matter in traps in this area, Fischer et al. (1996) found that coccolithophorids (coccoliths and coccospheres) constitute a dominant part of the particulate matter. The close correlation of organic carbon and carbonate sedimentation at $1000 \mathrm{~m}$ and $3000 \mathrm{~m}$ trap depths founded by Neuer et al. (1997) confirms the important role of coccolithophorids as primary producers and in the export flux in the Canary Island region during all seasons. These authors found a considerable increase in particle flux with depth, probably caused by the interaction of fast sinking particles originating from a primary source region close to the area with those advected laterally from closer to the NW African upwelling margin.

To calculate the quantity of calcium carbonate that has dissolved in the water column, the change in salinity normalised $A_{T}$ and $C_{T}$ values must be determined. It must be considered that the water masses present in this area may have had different $\mathrm{A}_{\mathrm{T}}$ and $\mathrm{C}_{\mathrm{T}}$ values at the time when the water masses were formed. Therefore, to calculate properly the $\Delta \mathrm{NA}_{\mathrm{T}}$ and $\Delta \mathrm{NC}_{\mathrm{T}}$ values, the preformed values $\left(\mathrm{NA}_{\mathrm{T}}{ }^{\circ}\right.$ and $\left.\mathrm{NC}_{\mathrm{T}}{ }^{\circ}\right)$ must be determined. Given the preformed values in a body of water and its present values, it is possible to determine the ratio of in situ inorganic and organic carbon decomposition. Under the assumption that $\mathrm{A}_{\mathrm{T}}$ is not affected by the invasion of anthropogenic $\mathrm{CO}_{2}$, we do not have to differentiate between historical and contemporary $\mathrm{NA}_{\mathrm{T}}{ }^{\circ}$ values. However, the $\mathrm{NC}_{\mathrm{T}}{ }^{\circ}$ values must be corrected for the injection of anthropogenic $\mathrm{CO}_{2}$. Failure to correct the $\mathrm{NC}_{\mathrm{T}}{ }^{\circ}$ values for anthropogenic $\mathrm{CO}_{2}$ may result in an error of 0.05-0.07 in the inorganic carbon to organic carbon ratio (Chen, 1990). The estimated amount of excess $\mathrm{CO}_{2}$ in this area is $\approx 62 \mu \mathrm{mol} / \mathrm{kg}$ (Körtzinger et al., 1998). Several authors (Edmon, 1974; Chen and Pytkowicz, 1979; Körtzinger et al., 1998) have reported linear correlation between the potential temperature $\theta$ and salinity normalized values of surface $A_{T}$ and $\mathrm{C}_{\mathrm{T}}$. The linear regressions calculated from our data set (this cruise and unpublished data, $n=42$ ) in order to calculate the preformed values for the deep waters in this area are given by

$$
\begin{aligned}
& \mathrm{NA}_{\mathrm{T}_{\mathrm{o}}}{ }^{\mathrm{o}}=2294.3( \pm 3.4)-0.27( \pm 0.17) \theta \\
& \mathrm{NC}_{\mathrm{T}}=2183.7( \pm 6.2)-10.02( \pm 0.80) \theta
\end{aligned}
$$

Using Equations 5 and 6, the ratio of carbon contributed to the waters from inorganic sources (IC) to carbon derived from the decomposition of organic matter (OC) can be calculated from Equations 7 to 9 (Chen et al., 1982; 1987; Chen, 1990)

$$
\begin{gathered}
\Delta \mathrm{NA}_{\mathrm{T}}=\mathrm{NA}_{\mathrm{T}(\text { measured })}-\mathrm{NA}_{\mathrm{T}}{ }^{{ }^{\circ}} \\
\Delta \mathrm{NC}_{\mathrm{T}}=\left(\mathrm{NC}_{\mathrm{T}(\text { measured }}-\mathrm{NC}_{\mathrm{T}}{ }^{\circ}\right)+62 \\
\mathrm{IC} / \mathrm{OC}=\left(0.15094 \Delta \mathrm{NC}_{\mathrm{T}}+\Delta \mathrm{NA} \mathrm{T}_{\mathrm{T}}\right) /\left(2 \Delta \mathrm{NC}_{\mathrm{T}}-\Delta \mathrm{NA}_{\mathrm{T}}\right)
\end{gathered}
$$

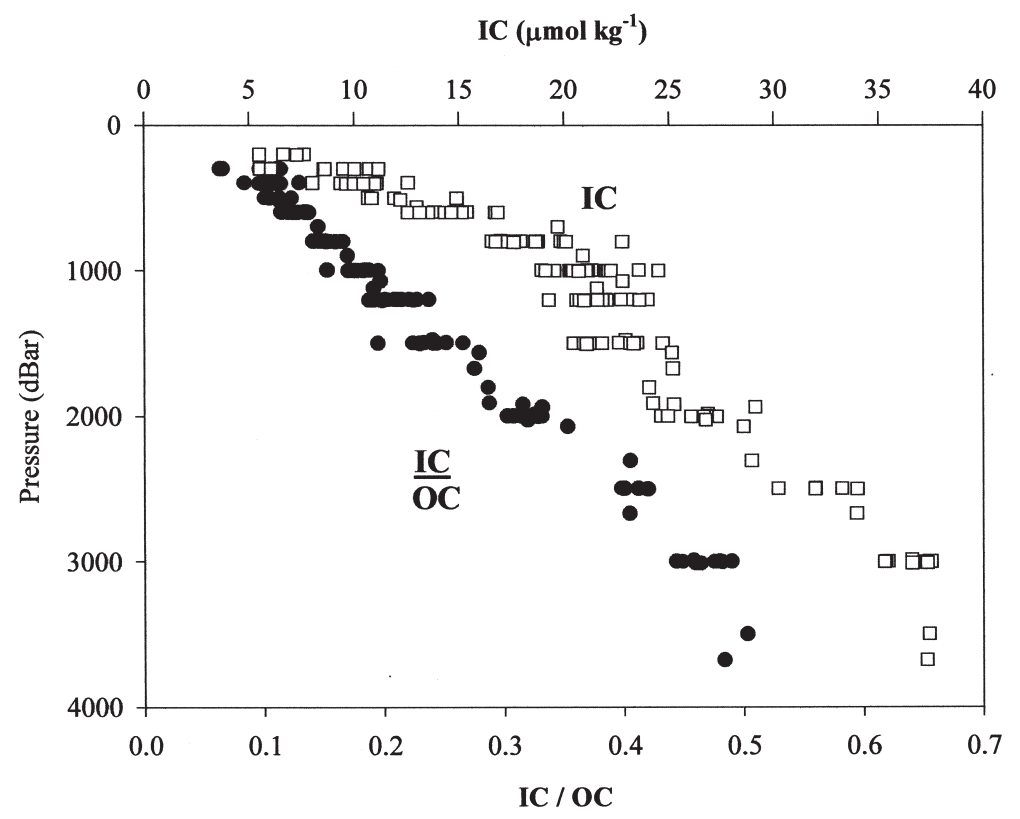

FIG. 5. - Ratio of carbon derived from the dissolution of calcium carbonate (IC) to carbon derived from the decomposition of organic matter (OC) calculated from Equations 7 to 9 (closed circles) and inorganic carbon in the water column contributed by the dissolution of carbonate particles, IC, determined from Equation 10 (open squares) over the water column. 
The IC/OC was calculated for waters deeper than $300 \mathrm{~m}$ and is shown in Figure 5. The IC/OC ratio increases from 0.07 at $300 \mathrm{~m}$ to 0.5 at $3000 \mathrm{~m}$. These values are higher than the ratio of 0.17 found in the Sea of Japan (Chen et al., 1995) and 0.36 found in the North Pacific (Chen, 1990), and similar to the value of 0.52 found in the Bering Sea (Chen, 1993). An IC/OC value of 0.5 indicates that approximately $34 \%$ of the carbon in the deep Canary area is contributed by the dissolution of carbonate particles. It should be pointed out that an error of $15 \%$ in the amount of excess $\mathrm{CO}_{2}$ in this area only contributes in an error of $2 \%$ in the IC/OC ratio. Our results demonstrate that far more carbon is added to the deep ocean from the decomposition of organic matter than from the dissolution of carbonates. Neuer et al. (1997) obtained that the flux of organic carbon explained more than $70 \%$ of the variability of the sedimentation of carbonate and lithogenic material. The increase in IC/OC with depth indicates that carbonate dissolution increases as a function of depth relative to the rate of decomposition. This is consistent with saturation state calculations, which demonstrate that deep waters are more undersaturated with respect to carbonate than shallow waters.

The quantity of inorganic carbon in the water column contributed by the dissolution of carbonate particles may be calculated from Equation 10 considering $\mathrm{IC}+\mathrm{OC}=\Delta \mathrm{NC}_{\mathrm{T}}$ (Sabine et al., 1995)

$$
\mathrm{IC}=0.07018 \Delta \mathrm{NC}_{\mathrm{T}}+0.4649 \Delta \mathrm{NA}_{\mathrm{T}}
$$

The IC at $300 \mathrm{~m}$ is approximately $7 \mu \mathrm{mol} \mathrm{kg}^{-1}$, increasing with depth to $37.5 \mu \mathrm{mol} \mathrm{\textrm {kg } ^ { - 1 }}$ at $3700 \mathrm{~m}$. Again, an error of $15 \%$ in the amount of excess $\mathrm{CO}_{2}$ in this area only contributes in an error of less than $1 \mu \mathrm{mol} \mathrm{kg}{ }^{-1}$ in the IC. The increase in IC demonstrates that the dissolution of carbonate particles (aragonite and calcite) increases with depth as they sink through the water column. This increase in IC must therefore be primarily due to the dissolution of aragonite particles.

\section{ACKNOWLEDGEMENTS}

We wish to thank captain and crew of R.V. POSEIDON for their excellent cooperation during the cruise. Many thanks to chief scientist G. Sidler for a perfect organization and for adjusting the cruise plan to our needs. Three anonymous reviewers provided very constructive comments.

\section{REFERENCES}

Anderson, L.A. - 1995. On the hydrogen and oxygen content of marine phytoplankton. Deep-Sea Res. I, 42: 1675-1680.

Arhan, M.A., A. Colin De Verdière and L. Memery. - 1994. The Eastern boundary of the subtropical North Atlantic. J. Phys. Oceanogr., 24: 1295-1316.

Broeckers, W.S. and T.H. Peng. - 1982. Tracers in the sea. Eldigio Press, Palisades, NY, 690 pp.

Broeckers, W.S. and T. Takahashi. - 1981. Hydrography of the Central Atlantic-IV. Intermediate water of Antartic origin. Deep-Sea Res., 286: 177-193.

Chen, C.A. - 1990. Rates of calcium carbonate dissolution and organic carbon decomposition in the North Pacific Ocean. $J$. Oceanograph. Soc. Jpn., 46: 201-210.

Chen, C.A. - 1993. Carbonate chemistry of the wintertime Bering Sea marginal ice zone. Cont. Shelf Res., 13: 67-87.

Chen, C.A. and R.M. Pytkkowicz. - 1979. On the total $\mathrm{CO}_{2}$-titration alkalinity-oxygen system in the Pacific Ocean. Nature, 281:362-365.

Chen, C.A., R.M. Pytkowicz and E.J. Olson. - 1982. Evaluation of the calcium problem in the South Pacific. Geochem. J., 100:1-10.

Chen, C.A. and S. Wang. - 1995. Carbonate chemistry of the sea of Japan. J. Geophys. Res., 100: 13737-13745.

Del Valls, T.A. and A.G. Dickson. -1998 . The $\mathrm{pH}$ of buffers based on 2-amino-2-hydroxymethyl-1,3-propanediol ("tris") in synthetic sea water. Deep-Sea Res. I, 45: 1541-1554.

Deuser, W.G., E.H. Ross and R.F. Anderson. - 1981. Seasonality in the supply of sediments to the deep Sargasso Sea and implications for the rapid transfer of matter to the deep ocean. DeepSea Res., 28: 495-505.

Dickson, A.G. - 1981. An exact definition of total alkalinity and a procesure for the estimation of alkalinity and total $\mathrm{CO}_{2}$ from titration data. Deep-Sea Res., 28: 609-623.

Dickson, A.G. and F.J. Millero. - 1987. A comparison of the equilibrium constants for the dissociation of carbonic acid in seawater media. Deep-Sea Res. I, 34. - 1733-1743.

Dickson, A.G. and C. Goyet (Eds). - 1994. DOE Handbook of methods for the analysis of the various parameters of the carbon dioxide system in sea water. Version 2. ORNL/CDIAC-74.

Edmon, J.M. - 1974. On the dissolution of carbonate and silicate in the deep ocean. Deep-Sea Res., 21: 455-480.

Fischer, G.S. Neuer, G. Krause and G. Wefer. - 1996. Short-term sedimentation pulses recorded with a fluorescence sensor and sediment traps in $990 \mathrm{~m}$ water depth in the Canary basin. Limnol. Oceanogr. 41: 1354-1359.

Fraga, F. and F.F. Pérez. - 1990. Transformaciones entre composición química del fitoplancton, composición elemental y relación de Redfield. Sci. Mar., 54: 69-76.

Fraga, F., A.F. Ríos, F.F. Pérez and F.G. Figueiras. - 1998. Theoretical limits of oxygen:carbon and oxygen:nitrogen ratios during photosynthesis and mineralisation of organic matter in the sea. Sci. Mar., 62: 161-168.

González-Dávila, M, J.M. Santana-Casiano, O. Llinás and M.J. Rueda. - 2000. Carbon dioxide and nutrient characteristics of water masses in the European Station for Time Series in the Ocean at the Canary Islands. Deep-Sea Res. II, submitted.

Houghton, J.T., L.M. Filho, B.A. Callander, N. Harris, A. Kattenberg and K. Maskell. - 1995. Climate changed 1995: The Science of climate change. Intergov. Panel on Clim. Change, Cambridge. England, 1996.

Klein, B. and G. Siedler. - 1989. On the origin of the Azores current. J. Geophys. Res., 94: 6159-6168.

Knoll, M., T.J. Múller and G. Siedler. - 1998. ESTOC/CANIGO cruises with FS Posiedon cruise 202/1, 212, 233, 237/3. Berich. Inst. Meeresk. Kiel, 302, 78 pp.

Körtzinger A., L. Mintrop and J.A. Duinker. - 1998. On the penetration of anthropogenic $\mathrm{CO}_{2}$ into the North Atlantic Ocean. $J$. Geophys. Res., 103: 18681-18689.

Lee, K., F.J. Millero and R. Wanninkof. - 1997. The carbon dioxide system in the Atlantic Ocean. J. Geophys. Res. 102:1569315707.

Lee K, F.J. Millero, R.H. Byrne, R.A. Feely and R. Wanninkhof. 2000. The recommended dissociation constants for carbonic acid in seawater. Geophys. Res. Letters, 27: 229-232.

Llinás, O., A. Rodríguez de León, G. Siedler and G. Wefer. - 1999. Technical Reports of the "Canarian Institute of Marine Sciences”. Dirección General de Universidades e Investigación, 
Gobierno de Canarias. 152 pp.

Measures, C.I., P.A. Yeats and D. Schmidt. - 1995. The hydrographic setting of the IOC baseline cruise to the eastern Atlantic $30^{\circ} \mathrm{S}$ to $35^{\circ}$. Mar. Chem., 49: 243-252.

Millero, F.J. - 1995. Thermodynamics of the carbon dioxide system in the oceans. Geochim. Cosmochim. Acta, 59: 661-667.

Mintrop, L., M. Pérez, F.F. González-Dávila, J.M. Santana-Casiano and Körtzinger, A. - 2000. Alkalinity determination by potentiometry: intercalibration using three methods. Ciencias Marinas, 26: 23-37.

Neuer, S., V. Ratmeyer, R. Davenport, G. Fischer and G. Wefer. 1997. Deep water particle flux in the Canary Islands region: seasonal trends in relation to long term satellite derived pigment data and lateral sources. Deep-Sea Res., 44: 1451-1466.

Newton, P.P., R.S. Lampit, T.D. Jickells, P. King and C. Boutle. 1994. Temporal and spacial variability of biogenic particles fluxes during the JGOFS northeast Atlantic process studies at 47 N, 20 W. Deep Sea Res., 41: 1617-1642.

Post, W.M., T.H. Peng, W.R. Emanuel, A.W. King, V.H. Dale and D.L. Deangelis. - 1990. The global carbon cycle. Am. Sci., 78: 310-326.

Rios, A.F., F.F. Perez and F. Fraga. - 1992. Water masses in upper and middle North Atlantic Ocean East of the Azores. Deep-Sea Res 39: 645-658.

Sabine, C.L., F.T. Mackenzie, C. Winn and D.M. Karl. - 1995
Geochemistry of carbon dioxide in seawater at the Hawaii Ocean Time series station, ALOHA. Global Biogeochem. Cycles, 9: 637-651.

Stramma, L. and G. Siedler. - 1988. Seasonal changes in the North Atlantic subtropical gyre. J. Geophys. Res., 93: 8111-8118.

Stumm, W. and J.J. Morgan. - 1981. Aquatic chemistry. $2^{\text {nd }}$ Ed. Wiley. New York.

Takahashi T., J. Olafsson, J. Goddard, D.W. Chipman and S. Sutherland. - 1993. Seasonal variation of $\mathrm{CO}_{2}$ and nutrients in the high-latitude surface oceans: A comparitive study. Global Biogeochem. Cycles, 7: 843-878.

Takahashi, T., T.T. Takahashi and S.C. Sutherland. - 1995. An assessment of the role of North Atlantic as a $\mathrm{CO}_{2}$ sink. Phil. Trans. Roy. Soc. London, Series B, 348: 143-152.

Takahashi, T., R.A. Feely, R. Weiss, R.H. Wanninkhof, D.W. Chipman, S. Sutherland and T.T. Takahashi. - 1997. Global air-sea flux of $\mathrm{CO}_{2}$ : an estimate based on measurements of sea-air $\mathrm{pCO}_{2}$ difference. Proc. Nat. Acad. Sci., 94: 8292-8299.

Tans, P.P., I.Y. Fung and T. Takahashi. - 1990. Observational constraints on the global atmospheric $\mathrm{CO}_{2}$ budget. Science, 247: 1431-1438.

Wanninkhof, R. - 1992. Relationship between wind speed and gas exchange. J. Geophys. Res., 97: 7373-7382.

Willenbrink, E. - 1982. Wassermassenanalyse im tropischen und subtropischen Nordostatlantik. Berich. Inst. Meeresk. Kiel, 96: 1-72 . 
